\title{
Prevalence of Iron Deficiency Anemia and its Biochemical Parameters among the Selected School- going Under-priviledged Children in Dhaka City
}

\author{
DEENA AS HUSSAIN, ${ }^{1}$ MS AREFIN, ${ }^{2}$ BUSHRA HUSSAIN,${ }^{3}$ ALPANA SARKER ${ }^{4}$
}

\begin{abstract}
Iron deficiency is a serious health complication particularly in developing countries, which is usually caused due to poor nutrition, genetic disorders and chronic infections. Compared to developed countries prevalance of anaemia in developing and underdeveloped countries is very high, and children are the ones which are mostly affected. In this paper an attempt has been made to study the prevalance of anaemia among some school-going children in Dhaka. An attempt has also been made to assess the severity of anaemia and iron status among the school-going underprivileged children by measuring serum iron (SI), serum TIBC and serum ferritin (SF) and explore a relationship between haemoglobin level and various parameters of iron nutrition. A substantial number of indicators have been used in determining the iron deficiency.

Results obtained from the study show that two thirds of the study children are anaemic due to haemoglobin level below $12 \mathrm{gm} / \mathrm{dl}$. However, majority of them had mild anaemia (haemoglobin level between 10.0 to 11.9 $\mathrm{gm} / \mathrm{dl}$ ) and only a few of them had moderate anaemia (haemoglobin level between 7.0 to $9.9 \mathrm{gm} / \mathrm{dl}$ ). None of the study population had severe anaemia (haemoglobin level below $7.0 \mathrm{gm} / \mathrm{dl}$ ). Results also show that only 10 of the study population (6\%) were found to have significantly low serum iron, low serum ferritin and high serum iron binding capacity (TIBC) as compared to that of the students who had normal haemoglobin level.
\end{abstract}

\section{Introduction}

Anaemia has long been recognized as a major global health problem affecting a considerable proportion of the World's population (WHO, 1996). It is defined as a fall of haemoglobin concentration below a statistically defined threshold lying at two standard deviations below the median of a healthy population of the same age, sex and stage of pregnancy (Gillispie, 1998). According to WHO, 500 million to 1 billion individuals representing $15-20 \%$ of the world population are presently affected by nutritional anaemia (Viteri, 1994). While epidemiological findings indicate the enormous extent of the problem globally, the developing countries are the most affected areas. It remains as a major problem with serious public health, social and economic consequences and continue to undermine human potential (ACC/SCN, 1991). The prevalence of anaemia in the developing countries is predictably three to four times higher than in industrialized countries. It is estimated that it occurs in $46-51 \%$ of the

1. Associate Professor, Dept. of Biochemistry, Shaheed Monsur Ali Medical College, Uttara, Dhaka.

2. Professor, Institute of Nutrition and Food Science, University of Dhaka.

3. MPH Student, Barkley, California, USA.

4. Medical Officer, Government Labour Welfare Centre, Ghorashal, Norshindi, Bangladesh.

Correspondence: Dr Deena AS Hussain, Associate Professor, Department of Biochemistry, Shaheed Monsur Ali Medical College, Uttara, Dhaka. children in less developed countries and $7-12 \%$ in more developed countries.

Nutrition survey of rural Bangladesh during 1975-76 reveals that about $70 \%$ of Bangladehi population suffers from anaemia with a mean haemoglobin value of $9.7 \mathrm{gm} /$ dl. An earlier survey during 1962-64 also reveals that almost half of the population studied had a significant degree of anaemia, and $10-12 \%$ were found suffering from severe anaemia. Average haemoglobin level in children (0-4 years) of neighboring Thailand is $11.2 \mathrm{gm} / \mathrm{dl}$ which is significantly higher than the values found in our studies. In one study it has been reported that about $52 \%$ of preschool children were found to be anaemic, but according to Bhatia et al (1990), $74 \%$ of the boys and $75 \%$ of the school girls between 5-14 years of age were anaemic. Prevalence of anaemia was also surveyed in urban Bangladesh and rural Chittagong Hill Tracts (Bangladesh Bureau of Statistics, 2003).

In view of the scarcity of relevant data this study has been taken up to estimate the prevalence of anaemia among the urban school going children and to undertake some of the biochemical indices such as serum iron, total iron binding capacity and serum ferritin to compliment the finding of the dietery and nutrients intake. The study is also aimed to compare these results with the anthropometric measurements of children in order to determine the nutritional status of the 
study population. It is expected that the study will enhance the extent of information available in this field and help the planners and policy makers to come up with an effective program to eliminate the high prevalence of anaemia. Thus the study will enable the community in having a healthy population free from anaemia and malnutrition.

\section{Objective}

To study prevalence of anaemia among the school going children in Dhaka city and the factors associated with it.

\section{Other objectives}

1. To asses the severity of anaemia and iron status among the school going children by measuring Serum Iron (SI), Serum TBIC \& Serum Ferritin (SF).

2. To find a correlation of biochemical parameters of iron status (SI, S.TBIC \& SF) with haemoglobin level.

3. To identify the different factors those influence the haemoglobin level.

\section{Limitations}

This was a limited study in a small population of cases with limited resources and time. It was a school based study and data were collected only from two schools which do not actually represent the total population. The data also did not represent the whole urban school going children population. Moreover, majority of the the studied children were from low income groups. So a large dimensional community-based study is recommended to validate the findings of this study. Similar multi-centered communitybased study involving large population and meta-analysis of result could be more meaningful and useful to validate the results of the present study.

\section{Delimitation}

Children with haematological disorders (e.g. Thalassemia sickle cell anaemia) were not included in this study.

\section{Materials And Methods}

This Cross Sectional study was carried out in Bangladesh Institute of Child Health, Sher-e-Bangla Nagar, Dhaka and Institute of Nutrition and Food Science, University of Dhaka during the period of July 2011 to June 2012. For this purpose a total of 164 samples have been taken from two selected schools named UCEP Hazi Shafiullah and Nilkhet High School located at Azimpur and New Market area of Dhaka City as per selection criteria. The technique used in sampling was on random basis.

\section{Ethical implication}

The study protocol was approved by the appropriate ethical review committee. Then both the verbal and written consent was taken from the respondent parents.

\section{Data collection instruments}

A questionnaire, developed for socioeconomic status, personal characteristics and 24 hour dietary recall, was pretested in the study place before finalization according to objectives of the study. Anthropometric indices and haematological parameters of blood including peripheral film were considered in the study.

\section{Data collection technique}

The purpose of the study was explained to the school authority and to the respondents. Data were collected from respondents through face to face interview by using the pre-tested structured questionnaire. Study population were clinically examined to determine the anaemia status and other nutritional deficiency features. Finally $3 \mathrm{ml}$ of venous blood was collected by disposable syringes with all aseptic precautions from each individual sample. Peripheral film was made and $1 \mathrm{ml}$ of blood was taken in a glass vial containing EDTA for haemoglobin estimation. The rest of the blood was transferred to centrifuged tube. Serum samples were separated, frozen and stored at $-20^{\circ}$ Celsius until biochemical analysis was carried out.

\section{Data processing and analysis}

After data collection, they were checked, verified and edited. Available data were compiled, tabulated and analyzed using a computer programme SPSS (version 12).

\section{Selection criteria}

Children aged 10 to 18 years as from both sexes were enrolled for the study. Cases having clinical manifestations of haematological disorders were excluded from the study.

\section{Results:}

The present cross-sectional study was designed to investigate the prevalence of anaemia among some underprivileged school going children in Dhaka City. The different biochemical indices of iron status such as haemoglobin, serum iron, total iron binding capacity and serum ferritin were estimated along with peripheral blood film examination to assess the iron status ot the study population. Furthermore, the effects of various socioeconomic profiles on the iron status were explored. One hundred and sixty four students were enrolled randomly from two different schools.

Table-I

Mean nutrient intake of the children (24 hours dietary recall) compared with $R D A$

\begin{tabular}{lcccc}
\hline Nutrient & Mean intake & SD & Mean RDA & \% RDA \\
\hline Energy(Kcal) & 1485.33 & 334.19 & 1941 & 83.8 \\
Protein(gm) & 39.45 & 16.23 & 24.60 & 160.4 \\
Iron(mg) & 7.85 & 6.37 & 10.0 & 78.5 \\
\hline
\end{tabular}


The table showing a 24 hour dietary recall reveals that the mean protein intake of the students (160.4 gm RDA) was more than the quantity in comparison with the mean energy intake $83.8 \%$ and iron intake $78.5 \%$.

Table-II

Distribution of study population according to BMI for age $(N=164)$

\begin{tabular}{lcc}
\hline BMI $\left(\mathrm{Kg} / \mathrm{m}^{2}\right)$ & Frequency & Present \\
\hline Normal & 94 & 57.3 \\
Thin & 70 & 42.9 \\
Total & 164 & 100.0 \\
\hline
\end{tabular}

Eighty of the study population (49\%) were 13-15 years of age. About 66 cases (40\%) belonged to $10-12$ years of age and rest $11 \%$ comprised 16 years and above. The smallest group was formed from 18 cases $(11 \%)$ of the total.

The total number of subjects having normal BMI for age $\left(>5^{\text {th }}\right.$ percentile) were 94 , of whom $42(44.7 \%)$ had mild anaemia and only $2(2.1 \%)$ had moderate anaemia, while number of subjects having low BMI for age $\left(<5^{\text {th }}\right.$ percentile $)$ is 70 , among which $58(82.9 \%)$ were mildly anaemic.

The following table shows the data after the total subjects were divided into two groups, anaemic and non-anaemic.

Table-III

Anaemia according to haemoglobin cut-off level $<12 \mathrm{gm} /$ $d l(N=164)$

\begin{tabular}{lccc}
\hline Group & $\begin{array}{c}\text { Hb. level } \\
\text { Mean } \pm \text { SD }\end{array}$ & $\begin{array}{l}\text { Number } \\
\text { of cases }\end{array}$ & Percent \\
\hline $\begin{array}{l}\text { Anaemic } \\
(\mathrm{Hb} .<12 \mathrm{~g} / \mathrm{dl})\end{array}$ & $10.8 \pm 0.7$ & 108 & 65.9 \\
$\begin{array}{l}\text { Non-anaemic } \\
(\mathrm{Hb} .>12 \mathrm{~g} / \mathrm{dl})\end{array}$ & $12.5 \pm 0.6$ & 56 & 34.1 \\
\hline Total & $11.4 \pm 1.0$ & 164 & 100 \\
\hline
\end{tabular}

The total study population was divided into two groups, anaemic ( $\mathrm{Hb}$ level $<12.0 \mathrm{gm} / \mathrm{dl}$ ) and non-anaemic ( Hb level $>12.0 \mathrm{gm} / \mathrm{dl}$ ) using a cut-off point of haemoglobin level 12.0 $\mathrm{gm} / \mathrm{dl}$ (recommended by WHO for anaemia in this age group). The mean haemoglobin level for anaemic and non-anaemmic groups were $10.8 \pm 0.7 \mathrm{gm} / \mathrm{dl}$ and $12.5 \pm 0.6 \mathrm{gm} / \mathrm{dl}$ respectively. Anaemia was observed $108(66 \%)$ cases and $56(34 \%)$ cases had no anaemia. One hundred (100/164; 61\%) subjects had mild anaemia( $\mathrm{Hb}$ level between 10.0-11.9 g/dl) whereas eight (8/164; 5\%) cases were moderately anaemic ( Hb level 7.0-9.9 $\mathrm{g} / \mathrm{dl})$. None of the subjects was found severely anaemic ( $\mathrm{Hb}$ level $<7.0 \mathrm{gm} / \mathrm{dl})$.
The difference was statistically significant $(\mathrm{p}<0.001)$.

Table-IV

Biochemical parameters of iron status among study population $(N=164)$

\begin{tabular}{lccc}
\hline Variable & Mean \pm SD & Median & Range \\
\hline Serum iron $(\mu \mathrm{g} / \mathrm{dl})$ & $50.7 \pm 23.3$ & 44.7 & $11.3-112.2$ \\
TBIC $(\mu \mathrm{g} / \mathrm{dl})$ & $340.8 \pm 59.7$ & 326.9 & $262.1-462.1$ \\
Serum ferritin $(\mu \mathrm{g} / \mathrm{dl})$ & $39.2 \pm 25.7$ & 33.5 & $2.0-118.0$ \\
\hline
\end{tabular}

Table IV shows mean serum iron level was 50.7 ( $\mathrm{SD} \pm 23.3$ ) $\mu \mathrm{g} / \mathrm{dl}$ which ranged from 11.30 to $112.20 \mu \mathrm{g} / \mathrm{dl}$. TIBC was $340.8(\mathrm{SD} \pm 59.7) \mu \mathrm{g} / \mathrm{dl}$. Mean TIBC in both the anaemic and non anaemic was significant $(\mathrm{p}<0.00)$. Serum ferritin level was $39.2(\mathrm{SD} \pm 25.7) \mu \mathrm{g} / \mathrm{dl}$. The mean serum iron level was lower in anaemic subjects. Low serum ferritin were observed in $6 \%$ of the subjects. The difference of mean serum ferritin level for anaemic and nonanaemic groups were statistically significant $(\mathrm{p}<0.00)$.

\section{Table-V}

Parameters of iron status among study population $(N=164)$

\begin{tabular}{lccc}
\hline Variable & $\begin{array}{c}\text { Normal } \\
\text { mean } \pm \text { SD }\end{array}$ & $\begin{array}{c}\text { Anaemic } \\
\text { mean } \pm \text { SD }\end{array}$ & $\begin{array}{c}\text { Level of } \\
\text { significance of } \\
\text { difference }\end{array}$ \\
\hline Serum iron $(\mu \mathrm{g} / \mathrm{dl})$ & $63.8 \pm 22.6$ & $44.0 \pm 20.7$ & $p<0.00$ \\
TIBC $(\mu \mathrm{g} / \mathrm{dl})$ & $317.2 \pm 50.2$ & $353 \pm 60.9$ & $p<0.001$ \\
Serum ferritin $(\mu \mathrm{g} / \mathrm{dl})$ & $56.6 \pm 31.8$ & $30.2 \pm 15.8$ & $p<0.00$ \\
\hline
\end{tabular}

The mean iron level for normal (non-anaemic) and anaemic groups were $63.8(\mathrm{SD} \pm 22.6) \mu \mathrm{g} / \mathrm{dl}$ and $44.0(\mathrm{SD} \pm 20.7) \mu \mathrm{g} / \mathrm{dl}$ respectively. The anaemic group was found to have statistically significant $(\mathrm{p}<0.001)$ lower serum iron level.

The mean TIBC level for normal (non-anaemic) and anaemic groups were and $317.2(\mathrm{SD} \pm 50.2) \mu \mathrm{g} / \mathrm{dl}$ and $353.0(\mathrm{SD} \pm 60.9)$ $\mu \mathrm{g} / \mathrm{dl}$ respectively and the difference was statistically significant $(\mathrm{p}<0.001)$. The mean ferritin level for normal (nonanaemic) and anaemic groups were 56.6 $(\mathrm{SD} \pm 31.8) \mu \mathrm{g} / \mathrm{dl}$ and $30.2(\mathrm{SD} \pm 15.8) \mu \mathrm{g} / \mathrm{dl}$ respectively and the difference was also statistically significant $(\mathrm{p}<0.001)$.

Table-VI

Severity of anaemia according to haemoglobin level $<12 \mathrm{gm} / \mathrm{dl}(\mathrm{N}=164)$

\begin{tabular}{lcccc}
\hline Degree of anaemia & No & $\begin{array}{c}\text { Serum iron } \\
(\mu \mathrm{g} / \mathrm{dl})\end{array}$ & TBIC & $\begin{array}{c}\text { Serum } \\
\text { ferritin }(\mu \mathrm{g} / \mathrm{l})\end{array}$ \\
\hline $\begin{array}{l}\text { Mild }(\mathrm{Hb} \text { cocn } \\
10.0-11.9 \mathrm{gm} / \mathrm{dl})\end{array}$ & 100 & $41.3 \pm 17.1$ & $374 \pm 30.1$ & $37.1 \pm 9.1$ \\
$\begin{array}{l}\text { Moderate }(\mathrm{Hb} \text { cocn } \\
7.0-9.9 \mathrm{gm} / \mathrm{dl})\end{array}$ & 8 & $33.3 \pm 15.2$ & $381 \pm 22.3$ & $22.7 \pm 7.2$ \\
Normal $(\mathrm{Hb}$ cocn $>12 \mathrm{gm} / \mathrm{dl}) 56$ & 63.8 & 317.2 & $56.6 \pm(81 \%)$ \\
\hline
\end{tabular}


Table VI shows the severity of anaemia according to haemoglobin level. The mean serum iron level was 41.3 $(\mathrm{SD} \pm 17.1) \mu \mathrm{g} / \mathrm{dl}$ in mildly anaemic subjects, while the same was 33.3 ( $\mathrm{SD} \pm 15.2) \mu \mathrm{g} / \mathrm{dl}$ in moderately anaemic subjects. In normal subjects the serum iron level was $63.8(\mu \mathrm{g} / \mathrm{dl})$.

Table-VII

Prevalence of iron deficiency anaemia of the study population $(N=164)$

\begin{tabular}{|c|c|c|c|}
\hline & Criterion & Number & Percent \\
\hline $\begin{array}{l}\text { Iron deficiency } \\
\text { anaemia }\end{array}$ & $\begin{array}{l}\text { Haemoglobin }<12 \mathrm{~g} / \mathrm{dl} \\
\& \text { Serum Ferritin }<12 \mu \mathrm{g} / \mathrm{dl}\end{array}$ & 10 & 6.1 \\
\hline $\begin{array}{l}\text { Non-iron deficiency } \\
\text { anaemia }\end{array}$ & $\begin{array}{l}\text { Haemoglobin }>12 \mathrm{~g} / \mathrm{dl} \\
\& \text { Serum Ferritin }>12 \mu \mathrm{g} / \mathrm{dl}\end{array}$ & 56 & 34.1 \\
\hline
\end{tabular}

10 cases of the subjects ( $6 \%$ of the total population) had iron deficiency anaemia as judged by combined $\mathrm{Hb}<12 \mathrm{gm} /$ 1 and serum ferritin level $<12 \mathrm{mg} / 1$.

Table VIII shows the socio-economic characteristics of the family of the study population particularly per capita income and family size. About the monthly income of the parents, $46 \%$ of the family's monthly income was d" Tk. 6000, 42\% had Tk.6000-9000 and 12\% had income e" Tk. 9000.

The study participants were divided into three groups according to per capita income, and the relationship of per capita income with haemoglobin level were explored. Significant differences ( $p>0.01)$ were observed in the mean haemoglobin levels between various per-capita income groups.

\section{Table-VIII}

Correlation of per-capita income, family size with haemoglobin level of the study population $(N=164)$

\begin{tabular}{lcccc}
\hline Variable & No & \multicolumn{2}{c}{ Haemoglobin level $(\mathrm{gm} / \mathrm{dl})$} & P-value \\
\cline { 3 - 4 } & & Mean & $95 \% \mathrm{CI}$ & \\
\cline { 1 - 4 } $\begin{array}{l}\text { Per-capita income } \\
<\text { or }=6000\end{array}$ & 76 & 11.04 & $10.7-11.3$ & \\
$6001-9000$ & 70 & 11.70 & $11.3-12.1$ & $>0.01$ \\
$>=9001$ & 18 & 11.60 & $11.1-12.1$ & \\
Family size & & & & \\
Small $<4$ & 56 & 11.61 & $11.1-12.1$ & \\
Medium 5-6 & 96 & 11.25 & $11.0-11.5$ & $>0.32$ \\
Large $>7$ & 12 & 11.29 & $10.1-12.4$ & \\
\hline
\end{tabular}

The mean haemoglobin level of the small sized families was $11.61(\mathrm{SD} \pm 1.24) \mathrm{gm} / \mathrm{dl}$ and that of medium sized families was $11.25(\mathrm{SD} \pm 1.14) \mathrm{gm} / \mathrm{dl}$. Excluding the third group which contains only 12 cases, the mean haemoglobin level was slightly higher in the students who came from medium sized families. However. the difference between groups was statistically significant $(\mathrm{p}<0.01)$ (Table- VIII).

\section{Discussion:}

Bangladesh is a developing country and located in the tropical region. So it is thought that the prevalence of anaemia in this country is expected to be high. The latest survey (2004-2005) show high prevalence of anaemia (49.5\%) in urban area (WHO, 2005). An updated survey in 2007 was also conducted by World Health Organization. Although there had been three national nutritional surveys carried out in Bangladesh previously to investigate the prevalence of anaemia, none of the surveys included school children as a distinct population group. Data on iron status of urban school attending children are not available, particularly the children coming from poor economic background. Therefore, the present study has been designed to investigate the prevalence of anaemia and iron status among the school attending underprivileged students in Dhaka City. Further attempt was also made to explore the relationship between haemoglobin level and various parameters of iron status.

Iron deficiency anaemia has been categorized on the basis of haemoglobin level. Haemoglobin level below $12 \mathrm{gm} / \mathrm{dl}$ was considered as iron deficiency anaemia. In case of mild anaemia the haemoglobin level was considered between 10.0 to $11.9 \mathrm{gm} / \mathrm{dl}$, while moderate anaemic had haemoglobin level between 7.0 to $9.9 \mathrm{gm} / \mathrm{dl}$. Severe anaemia was considered for haemoglobin level below $7.0 \mathrm{gm} / \mathrm{dl}$.

Considering only haemoglobin level below $12 \mathrm{gm} / \mathrm{dl}$ the present study showed that two thirds of the study children were anaemic. Majority of them had mild anaemia, and only a few of them had moderate anaemia. These findings are well consistent with the findings of Bangladesh National Nutrition Survey among the urban Bangladeshi population (Hussain M, 1976). Ayesha Molla et al (1992) too conducted a survey to estimate the prevalence of anaemia in urban slums and showed that $70 \%$ of the children were anaemic which was also well comparable to the findings of this study. None of the study population had severe anaemia.

Prevalence of iron deficiency showed a large variance depending upon the the indicators used. The limitation in using the level as a single criterion to determine the prevalence of iron deficiency is that it not only lacks specificity but is also relatively insensitive as there is a marked overlap in haemoglobin levels between normal and anaemic individuals (Garby et al, 1969). Only a few (6\%) were found to have iron deficiency anaemia using a combined cut-off of $\mathrm{Hb}<12 \mathrm{gm} / \mathrm{dl}$ and serum ferritin level $12 \mu \mathrm{g} / \mathrm{dl}$ (INACG, 1985). This finding is well consistent with that of $\mathrm{P}$ Winichagoon et al (2000) who had shown only $2 \%$ iron deficiency anaemia. When a more cut-off point was used for serum ferririn level of $<20 \mu \mathrm{g} / \mathrm{l}$, about $13.4 \%$ of the subjects were found anaemic. 
In the present study, 10 of the study population $(6 \%)$ were found to have significantly low serum iron, low serum ferritin and high serum iron binding capacity (TIBC) as compared to that of the students who had normal haemoglobin level. These results are similar to the findings of study in urban adolescent school girl (Ahmed et al, 1996).

Age, sex, nutritional status and family income have shown to have significant association with blood haemoglobin level of the study subjects. Age specific distribution of haemoglobin level showed that haemoglobin level rises significantly with the increase of age. This finding is well comparable to the finding of several other researchers, who reported that anaemia rates were minimal in older children and the prevalence of iron deficiency decreased with age. In our present study it was observed a little higher mean haemoglobin level in female than the male. This finding is not consistent with the findings of 1995-96 survey, which had shown a male preponderance that was observed in the nationwide previous survey. Thin (BMI for age $<5^{\text {th }}$ percentile) subjects were more anaemic in comparison to normal. This finding is in contrast to that of the study by Shabuddin AK et al (2000) who observed that $75 \%$ of the thin subjects were anaemic.

Socio-economic factors have shown a potential role in the differences in haemoglobin level, which has been observed in our study children from lower family income group. Comparable observations were reported by Ahmed F et al (1992). It was also observed that children from large families have lower haemoglobin than children from smaller families. Similar finding was reported by Ahmed F et al (1992).

\section{Conclusion:}

The ultimate aim for assessing iron deficiency in a population is to determine the extent of iron deficiency. While a substantial number of indicators was used for determining iron deficiency, they have not yet been evaluated for prediction. It is thus, difficult to interpret the results obtained with precision. Although iron deficiency anaemia was a common phenomenon in developing countries, a substantial part of the anaemia observed could not be explained whether it was due to iron deficiency. Therefore, it appears that there is a need to further identify the contributing factors of anaemia. In order to design an effective technique for the prevention and control, the aetiology of anaemia should be clearly investigated, which might help us to control anaemia as well as iron deficiency. Treatment plans may also be undertaken by iron supplementation to address the problem.

\section{Conflict of Interest : None}

\section{References:}

1. ACC/SCN. Controlling iron deficiency. Geneva; Administrative committee on Cordination; Subcommitttee on nutrition (ACC/SCN), 1991.

2. Ahmed F, Zaman M, Barua SM \& Saheen N,. Effect of family size and income on the biochemical indices of urban school children of Bangladesh. Eur J Clin Nutr 46' 465-473. 1992.

3. Ahmed F, Khan MR, Karim R, Taj S, Hydeti T, Farouque MO et al, (1996). Serum retinal and biochemical measures of iron status in adolescent girls in urban Bangladesh. Eur J Clin Nutr 50, 346-351.

4. Ahmed F, Khan MR, Islam M, Fuch G (2000). Anaemia and iron deficiency among adolescent girls in periurban Bangladesh. Eur J Clin Nutr 54, 678-683.

5. Ayesha Molla A, Kurshid M \& Molla (1992). Prevalence of iron deficiency anaemia of the children of the urban slums of Karachi Journal of Pak Med Asso 83 (11), 939-943.

6. BBS (2003), Anaemia prevalence survey of urban Bangladesh and rural Chittagong Hill Tracts 2003, Bangladesh Bureau Of Statistics, Statistics Division, Ministry of Planning, Government of the People's Republic of Bangladesh and UNICEF, Dhaka Bangladesh.

7. Bhatia, NS, Sinnghai, PK, Dhar, NR et al. Breath-holding spells: An analysis of 50 spells. Indian J. Pediatrics, 1990; 27:1073-1079

8. Garby L, Irnell L, Werner I., Iron Deficiency in Women of Fertile Age in Swedish Community, Acta Medica Scandinavica, 1969. 185: 113.

9. Gillispie S, In: Major issues in control of Iron Deficiency Micronutrient Initiative, Ottawa, Canada, 1998.

10. Hussain MA, Khan AK, Abedin Z, Ferdous Z, Ahmad K. Studies on the Nutritional Status of Expectant Mothers and Newborn Babies, Bangladesh Mmedical Research Council Bulletin, 1976, 2: 120-126.

11. Hussain, MA Effects of an Energy and Micronutrient Supplement on Skeletal Maturation in Undernourished Children in Indonesia, Eur. J. Clinical Nutrition, 2000; 54 : 74-79.

12. INACG (1985). Measurements of Iron Status, ILSI, 1985 Human Nutrition Institute, Washington DC, USA, 200055802.

13. Shabuddin AK, Talukder K, Talukder MK. Adolescent nutrition in a rural community in Bangladesh, Indian Journal of Pediatrics, 2000 Feb; 67(2) : 93-8.

14. Viteri, FE, Torun B. Anaemia and Physical Work Capacity. Clinics in Haematology, 1974, 3:609-626.

15. Winichagoon P,FucharoenS. Clinical and Hematological aspects of hemoglobinE beta-thalassemia, Current Opinion in Hematology 2000 March,7(2):106-12.

16. World Health Organization, 1996 (unpublished document WHO/NUT/96.10; available on request from Department of Nutrition for Health and Development, World Health Organization, 1211 Geneva 27, Switzerland.

17. WHO global database on anaemia, Vitamin and Mineral Nutrition Information System, 2005. 